\title{
Partial cutting in old-growth boreal stands: An integrated experiment
}

\author{
by Jean-Claude Ruel ${ }^{1, *}$, Daniel Fortin ${ }^{2}$ and David Pothier ${ }^{1}$
}

\begin{abstract}
The uncut boreal forest of eastern Québec is largely composed of stands with an irregular structure. Traditionally, even-aged silvicultural systems have been used for these forests but a strong interest has developed in alternative approaches. In 2004, an integrated experiment was established to provide a general assessment of harvesting uneven-aged boreal forest stands with a wide variety of treatments. Here, we summarize the key results of this experiment, which involved four silvicultural treatments differing in the level of tree retention: a clearcut with advance growth protection, a severe partial cut protecting small vigorous merchantable stems ( $75 \%-90 \%$ basal area removed), and two patterns of selection cutting (35\% basal area removed). We evaluated treatment effects on vegetation attributes and animal species assemblages. We also assessed whether or not selection cutting approaches could become broadly used on an operational basis by examining simple forms of application and assessing their economic profitability. We found that many attributes of old-growth forests can be maintained with selection cutting, even with simple approaches that do not invest in marking trees to cut. Unlike more severe cuts, silvicultural treatments with more than $55 \%$ tree retention largely maintain the animal assemblages associated with old forests. Financial analysis showed that selection cutting is profitable over the long time frame, but clearcutting remains more profitable. This greater profitability is related to the first entry, whereas future entries will be more profitable with selection cutting.
\end{abstract}

Keywords: old forests, silviculture, profitability, selection cutting, black spruce, balsam fir, ecosystem management, wildlife

\section{RÉSUMÉ}

La forêt boréale de lest du Québec comprend une abondance de vieilles forêts de structure irrégulière. De façon courante, ces forêts ont été récoltées sous un régime d’aménagement équienne mais un intérêt pour des méthodes alternatives sest développé. En 2004, une étude intégrée a été établie afin de comparer la récolte de peuplements irréguliers en forêt boréale à laide d'une diversité d’approches. Dans cet article, nous présentons une synthèse des principaux résultats de quatre traitements sylvicoles différant quant au niveau de rétention : coupe avec protection de la régénération et des sols, coupe avec protection des petites tiges marchandes (récolte de 75\%-90\% de la surface terrière), et deux patrons de jardinage (récolte de 35\% de la surface terrière). L'effet des traitements sur les attributs végétaux et les communautés animales a été examiné. Afin de vérifier la possibilité d'utiliser le jardinage sur une base opérationnelle, des approches simples ont été testées et leur rentabilité a été étudiée. Les résultats démontrent que plusieurs des attributs des vieilles forêts peuvent être maintenus avec les approches de jardinage, même sans martelage des tiges à récolter. Contrairement aux approches les plus utilisées, celles laissant plus de 55\% du couvert ont en général maintenu les assemblages despèces animales typiques des vieilles forêts. Les analyses financières ont démontré que les approches de jardinage présentaient un intérêt à long terme mais que lapproche de coupe totale demeurait plus rentable. Ceci est directement relié à la première intervention puisque les interventions futures devraient être plus rentables avec le jardinage.

Mots clés : vieilles forêts, sylviculture, rentabilité, jardinage, épinette noire, sapin baumier, aménagement écosystémique, faune

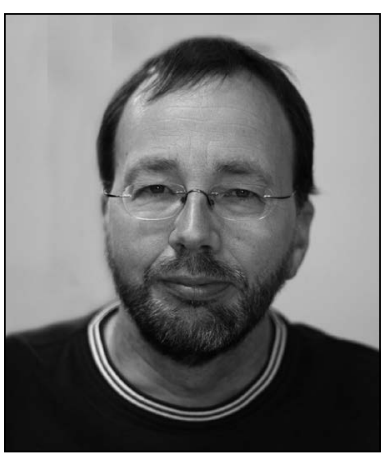

Jean-Claude Ruel

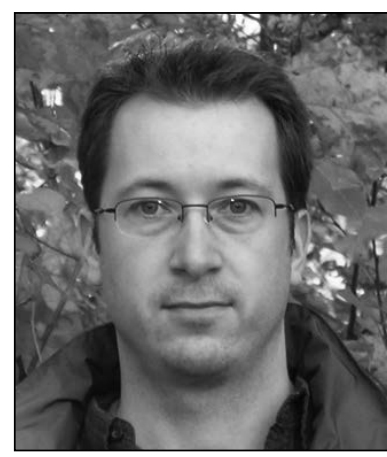

Daniel Fortin

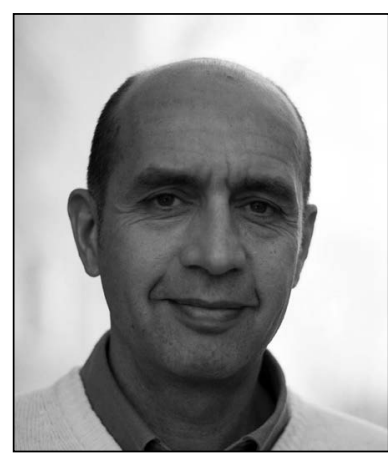

David Pothier

\footnotetext{
${ }^{1}$ Université Laval, Département des sciences du bois et de la forêt, Québec, Québec G1V 0A6.

* Corresponding author. E-mail: Jean-Claude.Ruel@sbf.ulaval.ca

${ }^{2}$ Université Laval, Département de biologie, Québec, Québec G1V 0A6
} 


\section{Introduction}

The eastern boreal forest of Québec is characterized by a long fire cycle that is associated with high precipitation (Foster 1983, Bergeron et al. 2001, Bouchard et al. 2008). In the absence of fire, forest gap dynamics largely shape the landscape by producing stands with irregular structure (De Grandpré et al. 2000, Côté et al. 2010). Such a complex stand structure should provide a greater variety of habitats at the stand-level in comparison with even-aged, regular stands, thereby favouring greater biodiversity (Hansen et al. 1991, McComb et al. 1993).

Traditionally, the boreal forest of Canada has been harvested by clearcut logging (Youngblood and Titus 1996). The practice currently prevailing in Québec involves the complete removal of the tree canopy while protecting the advance regeneration. When applied in old forests, however, this technique simplifies stand structure for more than 80 years (Groot et al. 2005, Bouchard et al. 2008). The loss of attributes that are typical of old forests could be detrimental to the preservation of local biodiversity (Hansen et al. 1991; Deans et al. 2003, McCarthy and Weetman 2006).

To adjust silvicultural practices to the local disturbance regime, Harvey et al. (2002) proposed a three-cohort management system where adapted practices would be especially required in third-cohort, late-successional stands. A first step in this direction was the introduction of a partial cutting method that retains stems with diameters smaller than 14 $\mathrm{cm}$, a technique known as CPPTM (Coupe avec Protection des Petites Tiges Marchandes) in Québec and HARP (Harvesting with Regeneration Protection) in Ontario (Groot et al. 2005). Yet, this treatment also simplifies the structure of irregular stands and, therefore, affects some of the key attributes of old-growth forests over the short term (Fortin et al. 2011). Selection cutting or irregular shelterwoods appear as a more promising avenue for maintaining ecosystem properties of late seral stage forests (Bergeron et al. 2007), but the financial profitability of selection cutting in these forests has been questioned. Factors that could affect profitability include slow growth rates, high harvesting costs related to small stem size, high transportation costs, low stand volume, and poor market value (McCarthy and Weetman 2006). One way to reduce costs and increase profits would be to avoid tree-marking and leave the final choice of which tree to harvest up to the harvester operator (Smith et al. 1997). Yet, improper selection of which trees to harvest can lead to increased mortality and reduced yield (Bédard and Brassard 2002), a situation that would be more likely to occur without marking trees to cut.

In 2004, an integrated experiment involving four silvicultural treatments was established in a landscape dominated by old-growth stands as part of the research program of the Natural Sciences and Engineering Research Council (NSERC)-Laval University Industrial Research Chair in Silviculture and Wildlife. The experiment was designed to provide a comprehensive assessment of the effects of harvesting stands of irregular structure with different levels of tree retention. A number of scientific articles and theses have been published covering various aspects of this experiment during the first three years of monitoring. In this review, we provide an overview of the key findings from these publications.

\section{An Integrated Experiment of Silvicultural Systems in Old-Growth Boreal Forest}

The study was conducted in northeastern Québec, in the eastern section of the black spruce-feather moss bioclimatic domain. Within this domain, mean annual temperature varies between $-2.5^{\circ} \mathrm{C}$ and $0.0^{\circ} \mathrm{C}$ (Robitaille and Saucier 1998). The growing season lasts about 140 days and annual precipitation ranges between 1000 and $1300 \mathrm{~mm}$ across the domain. Dominant surface deposits are of glacial origin with deep tills, shallow tills, and fluvioglacial deposits. Soil texture is generally sandy with an abundance of stones. Soil drainage varies from moderate to very poor. The most common soil types are podzols (Robitaille and Saucier 1998).

The study took place in four locations (between $68^{\circ} 00^{\prime} \mathrm{W}$ and $69^{\circ} 30^{\prime} \mathrm{W}$ and between $50^{\circ} 15^{\prime} \mathrm{N}$ and $51^{\circ} 15^{\prime} \mathrm{N}$ ), which were characterized by an abundance of stands over 100 years old, with an irregular or uneven-aged structure. These stands had never been harvested and their complex structure made them suitable for testing alternative harvesting methods. The selected stands were dominated by balsam fir (Abies balsamea [L.] Mill.) and black spruce (Picea mariana [Mill.]) BSP), which are species typical of old-growth stands of the region (Table 1). Regeneration was dominated by balsam fir. Each of the four experimental locations included one control and all four silvicultural treatments.

The first treatment is known as CPRS (Coupe avec Protection de la Régénération et des Sols) in Québec and as CLAAG (Careful Logging Around Advance Growth) in Ontario (Groot et al. 2005). CPRS is the dominant silvicultural practice in Québec and involves the removal of all merchantable stems (diameter at breast height $[\mathrm{DBH}]>9 \mathrm{~cm}$ ) while protecting the advance regeneration. The second treatment, CPPTM (HARP in Ontario), is a partial cut that involves the removal of stems with $\mathrm{DBH}$ greater than $14 \mathrm{~cm}$. It is operationally used in irregular boreal stands with an abundance of saplings and vigorous small merchantable stems (Riopel et al. 2000).

The two other treatments that were included in the study are simple variants of the selection cutting system (Ruel et al. 2007). The first variant involves a set of four cutting cycles that are scheduled at 60- to 70-year intervals. At the first entry, parallel 5-m-wide skid trails are established with 25-m-wide strips of forest between them. In 5-m strips adjacent to the skid trail, a partial cut removing $50 \%$ of the basal area is conducted, following selection guidelines that are adjusted to the local stand structure. A $15-\mathrm{m}$-wide strip is left untouched. At the second entry, harvesting takes place in the strip that was previously left untouched. At the third and fourth entries, harvesting occurs in portions of the stand that were partially cut at the first two entries.

Table 1. Initial stand characteristics

\begin{tabular}{|c|c|c|c|}
\hline & Mean & Minimum & Maximum \\
\hline Basal area $\left(\mathrm{m}^{2} / \mathrm{ha}\right)$ & 24.8 & 13.7 & 38.5 \\
\hline $\begin{array}{l}\text { Quadratic mean } \\
\text { diameter }(\mathrm{cm})\end{array}$ & 17.5 & 14.0 & 22.7 \\
\hline Tree density (stems/ha) & 1043 & 550 & 1650 \\
\hline $\begin{array}{l}\text { Percent basal area of balsam } \\
\text { fir in canopy }\end{array}$ & 55.0 & 2.8 & 100 \\
\hline $\begin{array}{l}\text { Percent balsam fir in } \\
\text { seedlings }\end{array}$ & 74.3 & 8.2 & 99.2 \\
\hline $\begin{array}{l}\text { Shannon index of diameter } \\
\text { distribution }\end{array}$ & 2.06 & 1.66 & 2.53 \\
\hline
\end{tabular}


After the first entry, new skid trails will be established and the machinery will avoid returning to previous skid trails to protect the established regeneration. Overall, this silvicultural technique aims to remove $35 \%$ of the basal area at each entry. We refer to it as selection cutting with temporary skid trails (SCt).

The second pattern of selection cutting involves permanent primary skid trails, $5 \mathrm{~m}$ wide, that are separated by a forest strip $30 \mathrm{~m}$ wide. These trails are reused at every cutting cycle, also scheduled at 60- to 70-year intervals. Secondary skid trails, which are $5 \mathrm{~m}$ long and arranged perpendicular to the main trails, provide access to the whole stand for partial harvesting and create small gaps where regeneration can establish. Harvest between secondary skid trails is done on an individual stem basis with the aim of removing $35 \%$ of basal area at the stand level. New secondary skid trails are established at each cutting cycle to protect the regeneration established in previous secondary skid trails. We refer to this silvicultural technique as selection cutting with permanent skid trails (SCp).

Each of the four silvicultural techniques (CPRS, CPPTM, SCt, and SCp) was allocated randomly to one 10- to 20-ha main unit at each location. An uncut control of similar size was kept at each location. Selection cutting treatments followed a "multi-treatment" approach (Meek and Lussier 2008), an approach specifically designed for spatially heterogeneous stands. Rather than applying a single harvesting rule, a limited number of easily identified local stand structures are defined, each having its own harvesting rule. A pre-cut sampling provided data on the relative abundance of each type of structure. From these data, a target stand structure was defined. This structure minimizes logging costs while maintaining a stable stand structure at each rotation, and providing a stable minimum volume of harvested trees with a target tree size of $24 \mathrm{~cm}$. Based on this target structure and the present distribution of the various local stand structures, a simple harvesting prescription was attached to each type of structure (Table 2). This approach avoids marking trees to cut. Stem selection is left to the harvester operator, who has to identify the local stand structure and apply the associated prescription (Ruel et al. 2007, Cimon-Morin et al. 2010a,b). In each of these main units, three $400-\mathrm{m}^{2}$ permanent sample plots were established randomly and monitored for living stems, snags, regeneration, and downed woody debris. For CPPTM, SCt and SCp that had a strong spatial pattern, plot shape was adjusted to capture a representative proportion of skid trails. All portions of the treatments were included in the sample. A section, close to one of the corners of the main unit was reserved to establish the second design (Fig. 1).
Fig. 1. Schematic representation of the experiment for one of the four experimental locations, with main units, where no tree marking is applied, and smaller units with tree marking. Italics: plots without marking; Underscored: plots with tree marking. Numbers refer to treatment: 1: CPRS (careful logging protecting advance growth), 2: CPPTM (harvesting of trees with $\mathrm{DBH}>14 \mathrm{~cm}$ ), 3: SCt (selection cutting with temporary skid trails), 4: SCp (selection cutting with permanent skid trails), 5: uncut control

Table 2. Tree harvesting targets ( $\%$ basal area to remove) by local stand structure and experimental location for selectively cut portions of the selection cutting treatments. Young and mature refer to the age of the most important tree layer.

\begin{tabular}{|c|c|c|c|c|c|}
\hline $\begin{array}{l}\text { Selection } \\
\text { cutting } \\
\text { approach }\end{array}$ & & Local structure & $\begin{array}{c}\text { Small trees } \\
(\text { DBH } 10-12 \mathrm{~cm})\end{array}$ & $\begin{array}{l}\text { Medium trees } \\
(\text { DBH } 14-20 \mathrm{~cm})\end{array}$ & $\begin{array}{c}\text { large trees } \\
(\mathrm{DBH}>20 \mathrm{~cm})\end{array}$ \\
\hline \multirow{7}{*}{ SCp } & \multirow{4}{*}{$\begin{array}{l}\text { All locations } \\
\text { AC- } 2, \text { A }\end{array}$} & Young & \multirow[t]{2}{*}{$0 \%$} & $0 \%$ & $100 \%$ \\
\hline & & Single layer, mature & & & \\
\hline & & Two layers, mature & \multirow[t]{2}{*}{$0 \%$} & \multirow{2}{*}{\multicolumn{2}{|c|}{$33 \%$}} \\
\hline & & Multiple layers & & & \\
\hline & \multirow[t]{3}{*}{$\mathrm{K}$, } & Single layer, mature & \multirow[t]{2}{*}{$0 \%$} & \multirow{2}{*}{\multicolumn{2}{|c|}{$50 \%$}} \\
\hline & & Two layers, mature & & & \\
\hline & & Multiple layers & $0 \%$ & \multirow[t]{3}{*}{$25 \%$} & \multirow[t]{3}{*}{$100 \%$} \\
\hline \multirow{7}{*}{ SCt } & \multirow[t]{3}{*}{ AC-1 } & Single layer, mature & $0 \%$ & & \\
\hline & & Two layers, mature & & & \\
\hline & & Multiple layers & $0 \%$ & $25 \%$ & $100 \%$ \\
\hline & \multirow{4}{*}{$\begin{array}{l}\text { All locations } \\
\text { All locations }\end{array}$} & Young & $0 \%$ & $0 \%$ & $100 \%$ \\
\hline & & Single layer, mature & $0 \%$ & $67 \%$ & $100 \%$ \\
\hline & & Two layers, mature & & & \\
\hline & & Multiple layers & & & \\
\hline
\end{tabular}


A second experimental design was nested within the reserved sections of the main units. The feature distinguishing this secondary design from the main units is that trees to be cut, together with skid trails, were marked prior to cutting. This fine-scale experiment ensures that the full potential of the selection cutting approaches is captured by having a large number of replicates and a tightly controlled application of the treatment; the larger units enable us to look at operational effects, and the effects on wildlife requiring the use of larger treated areas. Thus, for three of the four locations, all treatments were applied with marking in small units $\left(2500 \mathrm{~m}^{2}\right)$ within each main unit (Fig. 1). Skid trails were identified prior to cutting and sample plot shape was adjusted to remain representative of skid trail proportion. Here also, all portions of the treatments were sampled. Permanent sample plots $\left(400 \mathrm{~m}^{2}\right)$ were established at the centre of each of these small units to monitor the same variables as for the main units: vegetation structural and compositional attributes, and richness and composition of major animal groups.

To evaluate the potential of the selection cuts, their shortterm effects (three years after harvesting) are examined. First, these effects on vegetation structural and compositional attributes typical of old-growth forests are compared to those of current operational practices. Then, treatments are compared regarding their effects on major animal communities. Finally, their financial profitability and future potential are discussed.

\section{Partial Cutting and Key Vegetation Attributes of Old-Growth Forests}

Harvesting can affect many vegetation attributes of old forests, such as canopy density, stand structural complexity, dead wood availability, and species composition. Reducing canopy density is likely to increase the presence and abundance of early successional species at the expense of late-successional ones (Annand and Thompson 1997, Simon et al. 2000, Vanderwel et al. 2007). The different silvicultural treatments that were tested as part of our experiment represent a broad gradient of harvest intensity and, therefore, a range of residual canopy. When tree marking was used, CPRS, CPPTM, SCt, and SCp removed 94\%, 85\%, $44 \%$ and $43 \%$ of the basal area, respectively (Table 3 ). The harvesting levels of CPRS and CPPTM reported here are consistent with the levels commonly reported elsewhere (Riopel et al. 2000, Groot 2002, Groot et al. 2005).

Subsequent mortality can add to the original effects of the treatment on canopy density. CPPTM is particularly prone to such post-harvest effects because of its low level of tree retention. In contrast, CPRS has few additional trees to lose after the treatment, whereas the relatively higher level of retention of SCt and SCp provides more effective protection against windthrow resulting in lower post-harvest mortality (Savill 1983, Ruel 1995). In fact, no significant increase in mortality relative to uncut stands was detected during the first three years following selection cutting (SCt or SCp) (Cimon-Morin et al. 2010a). However, a longer monitoring period could lead to different conclusions.

Stand structure is also strongly influenced by logging intensity. In the eastern boreal forest of Québec, it is estimated that irregular stand structures typical of old-growth forests would be present across more than $60 \%$ of the area (Boucher et al. 2003, Côté et al. 2010). CPRS left very few trees and, hence, few structural attributes. CPPTM also yielded a highly simplified stand structure, as shown by a strong decrease in Shannon diversity of DBH distributions (Table 3). In contrast, Shannon indices of stands that had been harvested by selection cutting were similar or very close to those of uncut forests, and remained within the range typical of uneven-aged, irregular forests (Boucher et al. 2003). Large stems are usually the most vulnerable after partial cutting (Savill 1983, Ruel 1995) and their increased mortality could affect canopy structural diversity. If mortality, especially that of large stems, remains within the levels that were observed during the first three years after harvesting, a complex structure similar to that of old-growth forests should be maintained over time with both selection cutting approaches.

Table 3. Mean (standard error) forest attributes by treatment when trees are marked prior to cutting. Treatments associated with the same letter do not differ significantly (protected LSD, $p>0.05$ ). Adapted from Cimon-Morin et al. (2010a) and Légaré et al. (2011). CPRS: careful logging protecting advance growth; CPPTM: harvesting of trees with DBH > $14 \mathrm{~cm}$; SCt: selection cutting with temporary skid trails; SCp: selection cutting with permanent skid trails

\begin{tabular}{|c|c|c|c|c|c|}
\hline \multirow[b]{2}{*}{ Variable } & \multicolumn{5}{|c|}{ Treatment } \\
\hline & CPRS & СРPТМ & SCt & SCp & Control \\
\hline Basal area removed ${ }^{\star}(\%)$ & $\begin{array}{c}94 \\
(0.9)\end{array}$ & $\begin{array}{c}85 \\
(2.0)\end{array}$ & $\begin{array}{c}44 \\
(3.6)\end{array}$ & $\begin{array}{c}43 \\
(4.4)\end{array}$ & \\
\hline Shannon index of DBH distribution after harvesting & - & $\begin{array}{l}0.99 \mathrm{c} \\
(0.07)\end{array}$ & $\begin{array}{l}1.94 \mathrm{ab} \\
(0.06)\end{array}$ & $\begin{array}{l}1.85 b \\
(0.08)\end{array}$ & $\begin{array}{l}2.09 \mathrm{a} \\
(0.04)\end{array}$ \\
\hline Percent basal area of fir in the canopy after cutting & $\begin{array}{l}71 \mathrm{a} \\
(8)\end{array}$ & $\begin{array}{c}69 \mathrm{a} \\
(6)\end{array}$ & $\begin{array}{l}65 \mathrm{a} \\
(6)\end{array}$ & $\begin{array}{l}60 \mathrm{a} \\
(6)\end{array}$ & $\begin{array}{c}56 \mathrm{a} \\
(5)\end{array}$ \\
\hline $\begin{array}{l}\text { Percent fir (number of seedlings) in small regeneration } \\
(\mathrm{h}<5 \mathrm{~cm}) \text {, three years after harvesting }\end{array}$ & $\begin{array}{l}66 c \\
(7)\end{array}$ & $\begin{array}{c}76 \mathrm{bc} \\
(4)\end{array}$ & $\begin{array}{l}87 \mathrm{ab} \\
(2)\end{array}$ & $\begin{array}{c}77 \mathrm{bc} \\
(6)\end{array}$ & $\begin{array}{l}95 \mathrm{a} \\
(3)\end{array}$ \\
\hline Snag volume $\left(\mathrm{m}^{3} / \mathrm{ha}\right)$, two to three years after harvesting & $\begin{array}{l}5 c \\
(2)\end{array}$ & $\begin{array}{l}8 \mathrm{~b} \\
(1)\end{array}$ & $\begin{array}{l}25 \mathrm{a} \\
(4)\end{array}$ & $\begin{array}{l}24 \mathrm{a} \\
(5)\end{array}$ & $\begin{array}{l}36 \mathrm{a} \\
(7)\end{array}$ \\
\hline $\begin{array}{l}\text { Volume of downed woody debris, three years after } \\
\text { harvesting }\left(\mathrm{m}^{3} / \mathrm{ha}\right)\end{array}$ & $\begin{array}{l}75 a \\
(12)\end{array}$ & $\begin{array}{l}82 \mathrm{a} \\
(11)\end{array}$ & $\begin{array}{c}78 \mathrm{a} \\
(11)\end{array}$ & $\begin{array}{c}87 \mathrm{a} \\
(13)\end{array}$ & $\begin{array}{l}85 a \\
(11)\end{array}$ \\
\hline Mortality after three years (\% basal area) & $\begin{array}{c}35 \mathrm{ab} \\
(7)\end{array}$ & $\begin{array}{c}39 a \\
(6)\end{array}$ & $\begin{array}{c}28 \mathrm{abc} \\
(5)\end{array}$ & $\begin{array}{c}22 \mathrm{bc} \\
(5)\end{array}$ & $\begin{array}{l}14 \mathrm{c} \\
(4)\end{array}$ \\
\hline
\end{tabular}

*Treatment main effect could not be tested because of a significant site $\times$ location interaction 
Harvesting generally reduces the amount of dead wood (Desponts et al. 2004), which could affect old-growth forest attributes because coarse woody debris is a critical habitat component for many organisms (Harmon et al. 1986, Hansen et al. 1991), from fungi to small mammals (Jonsson and Kruys 2001, Azeria et al. 2009, Lemaître et al. 2010, Janssen et al. 2011). Cimon-Morin et al. (2010a) found that, relative to uncut stands, all four treatments resulted in a decrease in basal area of snags. However, when snag abundance is expressed in terms of volume rather than basal area, Légaré et al. (2011) found no reduction in snag abundance after selection cutting, but they detected a particularly strong decrease following CPRS (Table 3). The effect of the treatment on snags was only observed for the volume of recent snags. Also, no treatment effect was detected on the volume of downed dead wood (Cimon-Morin et al. 2010a, Légaré et al. 2011).

A concern over an increase of balsam fir after harvesting these old-growth forests has been expressed (Grondin et al. 2003). Advance growth of balsam fir is generally more abundant than that of black spruce when both species are present together in the canopy (Ruel 1989). Moreover, balsam fir regeneration tends to respond faster to canopy opening (Doucet and Boily 1995). In our experiment, both CPRS and CPPTM increased balsam fir proportion in the canopy relative to their own precut values (Cimon-Morin et al. 2010a). However, for CPRS, the number of stems remaining remains negligible. Regardless of this effect, fir proportion in the residual canopy remains comparable to uncut controls (Table 3). None of the treatments increased the percentage of fir in the newly established regeneration. In fact, most of them reduced it (Table 3).

An increased abundance of balsam fir could strongly affect animal communities. For example, an increase in balsam fir eventually implies greater recruitment of dead wood from this species, and different beetle communities are found in snags of balsam fir and black spruce (Janssen et al. 2011). Also, moose (Alces alces L.) could benefit from increased fir abundance in this ecosystem, because fir boughs are an important component of its winter diet. An increase in the moose population could increase wolf (Canis lupus L.) density, which could have a negative effect on threatened caribou (Rangifer tarandus L.) populations through increased predation (Fortin et al. 2011). An increase in balsam fir is considered undesirable by logging companies because of the lower quality of its wood compared to that of black spruce. Moreover, fir is more vulnerable to spruce budworm (Choristoneura fumiferana Clemens), to decay, and to windthrow (Viereck and Johnston 1990, Ruel 2000, Grondin et al. 2003). Balsam fir enrichment would not be specific to our silvicultural techniques per se; rather, this response reflects natural succession processes in the absence of fire (Bouchard et al. 2008, Côté et al. 2010).

The effects of partial harvesting described above were obtained with pre-harvest marking of trees to be cut. This represents an ideal situation for treatment application. In an operational context involving a high number of small trees, tree marking would become difficult to apply. Interestingly, we found that tree marking, whether it was used or not, had almost no effect on forest structure and composition attributes (Table 4). The only significant effect recorded was lower cumulative mortality in the absence of tree marking, three years after logging.

Based on results from the small units, it can be concluded that the partial cuts tested show a great potential for maintaining key features of old forests. Results from the main units show that even simple approaches of selection cutting that leave flexibility to the harvester operator remain efficient in maintaining these features.

\section{Partial Cutting Old-Growth Stands and Animal Communities}

The effects of our silvicultural treatments on wildlife were assessed during the first three years after cutting by monitoring beetles, birds, small mammals, and Snowshoe Hare (Lepus americanus Erxleben) populations (Hodson et al. 2010, LeBlanc et al. 2010, Hodson 2011, Légaré et al. 2011). Because these animals were studied in the main units without prior marking of trees to harvest, the results are informative about what could be expected in an operational context.

Table 4. Mean [standard error] forest attributes for selection cutting treatments, with or without marking trees to cut. Adapted from Cimon-Morin et al. (2010b). SCt: selection cutting with temporary skid trails; SCp: selection cutting with permanent skid trails

\begin{tabular}{|c|c|c|c|c|c|}
\hline \multirow[b]{2}{*}{ Variable } & \multicolumn{2}{|c|}{ SCt } & \multicolumn{2}{|c|}{ SCp } & \multirow[b]{2}{*}{$\begin{array}{l}\text { significance of } \\
\text { tree marking }\end{array}$} \\
\hline & $\begin{array}{l}\text { with } \\
\text { marking }\end{array}$ & $\begin{array}{l}\text { without } \\
\text { marking }\end{array}$ & $\begin{array}{l}\text { with } \\
\text { marking }\end{array}$ & $\begin{array}{l}\text { without } \\
\text { marking }\end{array}$ & \\
\hline Residual basal area $\left(\mathrm{m}^{2} / \mathrm{ha}\right)$ & $\begin{array}{l}15.4 \\
(1.1)\end{array}$ & $\begin{array}{l}14.8 \\
(1.3)\end{array}$ & $\begin{array}{l}13.5 \\
(1.2)\end{array}$ & $\begin{array}{l}18.2 \\
(1.9)\end{array}$ & NS \\
\hline Shannon index of DBH distribution after harvesting & $\begin{array}{c}1.94 \\
(0.05)\end{array}$ & $\begin{array}{l}1.88 \\
(0.06)\end{array}$ & $\begin{array}{c}1.85 \\
(0.08)\end{array}$ & $\begin{array}{l}1.96 \\
(0.04)\end{array}$ & NS \\
\hline $\begin{array}{l}\text { Percent basal area of fir in the residual canopy } \\
\text { after harvesting }\end{array}$ & $\begin{array}{l}63 \\
(6)\end{array}$ & $\begin{array}{l}51 \\
(8)\end{array}$ & $\begin{array}{l}49 \\
(5)\end{array}$ & $\begin{array}{l}60 \\
(9)\end{array}$ & NS \\
\hline $\begin{array}{l}\text { Percent fir (number of seedlings) in small } \\
\text { regeneration }(\mathrm{h}<5 \mathrm{~cm}) \text {, three years after harvesting }\end{array}$ & $\begin{array}{l}87 \\
(2)\end{array}$ & $\begin{array}{l}83 \\
(5)\end{array}$ & $\begin{array}{l}77 \\
(6)\end{array}$ & $\begin{array}{l}86 \\
(3)\end{array}$ & NS \\
\hline $\begin{array}{l}\text { Snags basal area }\left(\mathrm{m}^{2} / \mathrm{ha}\right), \text { two to three years } \\
\text { after harvesting }\end{array}$ & $\begin{array}{l}5.0 \\
(0.8)\end{array}$ & $\begin{array}{c}6.0 \\
(0.8)\end{array}$ & $\begin{array}{c}4.5 \\
(0.7)\end{array}$ & $\begin{array}{c}6.4 \\
(1.0)\end{array}$ & NS \\
\hline $\begin{array}{l}\text { Volume of downed woody debris, three years after } \\
\text { harvesting }\left(\mathrm{m}^{3} / \mathrm{ha}\right)\end{array}$ & $\begin{array}{c}81 \\
(10)\end{array}$ & $\begin{array}{c}96 \\
(18)\end{array}$ & $\begin{array}{c}91 \\
(12)\end{array}$ & $\begin{array}{l}107 \\
(20)\end{array}$ & NS \\
\hline Mortality after three years (\% basal area) & $\begin{array}{l}28 \\
(5)\end{array}$ & $\begin{array}{l}14 \\
(5)\end{array}$ & $\begin{array}{l}22 \\
(5)\end{array}$ & $\begin{array}{l}10 \\
\text { (3) }\end{array}$ & $\mathrm{p}=0.01$ \\
\hline
\end{tabular}


Insects represent the most abundant animal group and have been used extensively to evaluate the effect of forest management on animal communities (Pohl et al. 2007). During part of their life, many insect species depend upon dead or dying wood, or wood-inhabiting fungi, or the presence of other saproxylic organisms. Insects may therefore be sensitive to harvest practices (Speight 1989) and provide valuable information on the impacts of deadwood management practices on animal communities. Relative to uncut forests, selection cuts and CPPTM increased the richness of both epigaeic saproxylic and non-saproxylic epigaeic beetles (Table 5). Abundance of flying saproxylic beetles was reduced after CPRS and CPPTM (Table 6; Légaré et al. 2011). Beetle species assemblages also differed among silvicultural treatments (Légaré et al. 2011). A strong increase in the abundance of open habitat species occurred with CPRS and CPPTM, whereas the impact was generally minor for selection cuts, except for non-saproxylic epigaeic beetles for which a small increase in the abundance of open habitat species, coupled with a small decrease of closed habitat species, was also noticed (Table 6). Treatment effects on saproxylic species were closely linked to their effects on snag basal area. Although CPPTM maintained a slightly higher volume of snags than did CPRS, treatment effects on beetle species assemblages were comparable. Fortin et al. (2011) reported a greater abundance of open-canopy species of ants and beetles, together with a lower abundance of closed-canopy species, when comparing CPPTM with uncut forests. These results suggest that the residual canopy in CPPTM is not sufficient to mitigate the short-term effects of cutting regardless of the impact on species richness. Selection cuts led to snag basal areas that were lower than those in uncut forests, without significant effects on snag volume, but these effects were still sufficient to alter species composition.

Mature-forest bird species, such as Brown Creeper (Certhia americana Bonaparte), Boreal Chickadee (Poecile hudsonica J.R. Forster), Ruby-crowned Kinglet (Regulus calendula L.), and Red-breasted Nuthatch (Sitta canadensis L.), were positively associated with SCt, SCp, and uncut stands. In contrast, early-seral-stage species, such as White-throated Sparrow (Zonotrichia albicollis Gmelin), Tennessee Warbler (Vermivora

Table 5. Mean (standard error)species richness (number of species by main experimental unit) for different animal groups, two to three years after harvesting. Values for beetles are log-transformed. Treatment values with the same letter are not significantly different $(p>0.05)$. For songbirds and small mammals, * denotes a significant difference with their paired uncut control. Data from Légaré et al. (2011) and LeBlanc (2009). CPRS: careful logging protecting advance growth; CPPTM: harvesting of trees with $\mathrm{DBH}>14 \mathrm{~cm}$; SCt: selection cutting with temporary skid trails; SCp: selection cutting with permanent skid trails

\begin{tabular}{lccccc}
\hline & CPRS & CPPTM & SCt & SCp & Control \\
\hline Flying saproxylic & $1.78 \mathrm{a}$ & $1.79 \mathrm{a}$ & $1.87 \mathrm{a}$ & $1.85 \mathrm{a}$ & $1.75 \mathrm{a}$ \\
beetles & $(0.03)$ & $(0.02)$ & $(0.04)$ & $(0.04)$ & $(0.04)$ \\
Epigaeic & $1.54 \mathrm{c}$ & $1.62 \mathrm{a}$ & $1.61 \mathrm{a}$ & $1.64 \mathrm{a}$ & $1.55 \mathrm{bc}$ \\
saproxylic beetles & $(0.04)$ & $(0.04)$ & $(0.05)$ & $(0.04)$ & $(0.04)$ \\
Epigaeic non & $1.41 \mathrm{a}$ & $1.40 \mathrm{ab}$ & $1.31 \mathrm{~b}$ & $1.34 \mathrm{ab}$ & $1.19 \mathrm{c}$ \\
saproxylic beetles & $(0.03)$ & $(0.02)$ & $(0.03)$ & $(0.04)$ & $(0.04)$ \\
All beetles & $2.07 \mathrm{a}$ & $2.08 \mathrm{a}$ & $2.09 \mathrm{a}$ & $2.01 \mathrm{a}$ & $1.99 \mathrm{~b}$ \\
& $(0.02)$ & $(0.02)$ & $(0.03)$ & $(0.03)$ & $(0.02)$ \\
Small mammals & $3.75 \mathrm{a}(1.03)$ & $4.25 \mathrm{a}(1.03)$ & $5.00 \mathrm{a}(0.53)$ & $3.00 \mathrm{a}(0.57)$ & - \\
Forest birds & $4.87^{*} \mathrm{a}(0.80)$ & $7.83 \mathrm{~b}(1.31)$ & $7.30 \mathrm{~b}(0.86)$ & $7.60 \mathrm{~b}(0.89)$ & - \\
\hline
\end{tabular}

peregrina A. Wilson), Dark-eyed Junco (Junco hyemalis L.), and American Robin (Turdus migratorius L.) were more abundant in CPRS and CPPTM (LeBlanc 2009, LeBlanc et al. 2010). The effects of CPRS and CPPTM are consistent with previous observations that low retention levels $(<30 \%)$ would negatively affect mature forest species (Harrison et al. 2005, Vanderwel et al. 2009). Harrison et al. (2005) suggested that $50 \%$ retention ould be sufficient for maintaining most mature forest speVanderwel et al. (2009) suggested that some mature forest species, such as Brown Creeper, would still be affected by this retention level but that local extirpation would be unlikely. In our case, a 55\% retention level appeared to be effective in maintaining old-growth species, including the Brown Creeper.

The silvicultural treatments also influenced small mammal communities. The main effect was a change in the relative abundance of Red-backed Voles (Myodes gapperi Vigors) and Deer Mice (Peromyscus maniculatus Wagner). The Red-backed Vole is generally associated with habitats that provide protective cover from predators and that satisfy their high demands for water (Vanderwel et al. 2009). In our study, red-backed voles were most abundant in stands with high moss coverage, high vertical cover, and high conifer basal area, which are typical of high retention levels (Hodson et al. 2010, LeBlanc et al. 2010), i.e., uncut stands and selection cuts. Habitat preference of voles also varied as a function of their density, with uncut stands being selected over any of the four silvicultural treatments when vole abundance was low. The preference for uncut stands against selection cut stands disappeared, however, at high vole densities (Hodson et al. 2010). It remains that, while our observations support Vanderwel et al's (2009) assertion that retention levels $\geq 50 \%$ mitigate the impact of forest harvesting, vole populations are still impacted by such rather high retention levels. Moreover, the density dependence detected in habitat selection implies that vole populations in harvested stands were linked, to some extent, to the populations in adjacent uncut stands. This non-independence, together with edge effects (Deans et al. 2005), indicate that the impact of the silvicultural treatments might become more important farther in the cuts; hence, the impact would be overall stronger in larger cuts. Deer Mice were also influenced by the silvicultural treatments: individuals were more abundant in sites harvested by CPRS and CPPTM than in the other sites (LeBlanc et al. 2010). The Deer Mouse is an early successional species that generally benefits from low levels of retention (Steventon et al. 1998, Fuller et al. 2004).

Snowshoe Hares displayed a similarly strong reaction to the differences in logging intensity among silvicultural treatments. Hares are often selected to assess the impacts of forest harvesting disturbance because of the central role that they play in many ecosystems through their influence on plant and predator communities (Boutin et al. 1995, Dlott and Turkington 2000). In our study area, habitat selection by hare depended 
Table 6. Treatment effects on the abundance of forest animal species. Data sources: beetles, Légaré et al. (2011); songbirds and small mammals, LeBlanc et al. (2010). CPRS: careful logging protecting advance growth; CPPTM: harvesting of trees with DBH > $14 \mathrm{~cm}$; SCt: selection cutting with temporary skid trails; SCp: selection cutting with permanent skid trails. Based on multivariate ordinations: -: strong negative relationship with treatment; -: negative relationship with treatment; +: positive relationship with treatment; ++: strong positive relationship with treatment.

\begin{tabular}{|c|c|c|c|c|c|c|c|}
\hline & & CPRS & СРРТМ & SCt & SCp & Control & Key old forest attributes \\
\hline \multirow[t]{2}{*}{$\begin{array}{l}\text { Flying saproxylic } \\
\text { beetles }\end{array}$} & $\begin{array}{l}\text { Closed-habitat species: } \\
\text { Rhizophagus dimidiatus, } \\
\text { Epureae planulata }\end{array}$ & - & - & + & + & ++ & $\begin{array}{l}\text { - Basal area (spruce, fir) } \\
\text { - Snags }\end{array}$ \\
\hline & $\begin{array}{l}\text { Open-habitat species: } \\
\text { Pseudanostirus triundulatus }\end{array}$ & ++ & ++ & - & - & -- & \\
\hline \multirow[t]{2}{*}{$\begin{array}{l}\text { Epigaeic saproxylic } \\
\text { beetles }\end{array}$} & $\begin{array}{l}\text { Closed-habitat species: } \\
\text { Proteinus sp., Oxypoda } \\
\text { grandipennis }\end{array}$ & - & - & + & + & ++ & $\begin{array}{l}\text { - Basal area (spruce, fir) } \\
\text { - Snags } \\
\text { - Down dead wood }\end{array}$ \\
\hline & $\begin{array}{l}\text { Open-habitat species: } \\
\text { Hylobius congener, Dyrocoetes } \\
\text { autographus }\end{array}$ & ++ & + & - & - & - & - Mosses, sphagnum \\
\hline \multirow[t]{2}{*}{$\begin{array}{l}\text { Epigaeic non } \\
\text { saproxylic beetles }\end{array}$} & $\begin{array}{l}\text { Closed-habitat species: } \\
\text { Liogluta aloconotoides, } \\
\text { Tachinus frigidus }\end{array}$ & -- & - & - & - & ++ & $\begin{array}{l}\text { - Basal area (spruce, fir) } \\
\text { - Mosses, sphagnum }\end{array}$ \\
\hline & $\begin{array}{l}\text { Open-habitat species: } \\
\text { Parascydmus corpusculus, } \\
\text { Pterostichus adstrictus }\end{array}$ & ++ & + & + & + & - & \\
\hline \multirow[t]{2}{*}{ Forest birds } & $\begin{array}{l}\text { Closed-habitat species: } \\
\text { Brown Creeper, Boreal } \\
\text { Chickadee, Ruby-crowned } \\
\text { Kinglet, Red-breasted Nuthatch }\end{array}$ & - & - & ++ & ++ & ++ & $\begin{array}{l}\text { - Basal area (spruce, fir }<22 \mathrm{~cm} \text { ) } \\
\text { - Snags } \\
\text { - Vertical cover }\end{array}$ \\
\hline & $\begin{array}{l}\text { Open-habitat species: } \\
\text { White-throated Sparrow, } \\
\text { Tennessee Warbler, Dark-eyed } \\
\text { Junco, American Robin }\end{array}$ & ++ & + & - & - & - & \\
\hline \multirow[t]{2}{*}{ Small mammals } & $\begin{array}{l}\text { Closed-habitat species: } \\
\text { Red-backed Vole }\end{array}$ & - & - & + & + & + & $\begin{array}{l}\text { - Mosses } \\
\text { - Vertical cover }\end{array}$ \\
\hline & $\begin{array}{l}\text { Open-habitat species: } \\
\text { Deer Mouse }\end{array}$ & ++ & + & - & - & - & - Basal area (conifers) \\
\hline
\end{tabular}

on both hare density and differences in canopy cover between harvested stands and uncut forests. As hare density increased, the preference for uncut stands over SCt and SCp essentially vanished, whereas CPRS and CPPTM were strongly avoided, regardless of hare density (Hodson et al. 2010). Further, silvicultural treatment effects seemed to be more closely linked to local increases in predation risk than to decreases in browse availability (Hodson et al. 2010). Clearcut stands tend to remain poor-quality hare habitats for at least four years following harvest (Ferron et al. 1998). The higher residual canopy of CPPTM was not sufficient to maintain habitat use by hare over the short term (three years), but CPPTM could accelerate, relative to clearcuts, the recovery of mature forest habitat characteristics. In Quebec, it is expected that these stands will reach maturity10 years earlier than clearcut stands (MRNFPQ 2003, Pothier et al. 1995). Even though SCt and SCp seemed to create favorable habitat at high hare densities, hares were still impacted at low population levels.

The silvicultural treatments tested here would likely also influence animal species with large home ranges, but the size of the treated plots prevented us from investigating these effects. However, CPPTM and CPRS have been applied for some time at an operational level, thereby providing opportunities to examine its effects on moose and caribou. While both caribou and moose tend to avoid CPRS (Courbin et al. 2009, Fortin et al.
2011), only caribou avoided CPPTM relative to mature conifer forests, whereas moose did not. CPPTM thus appears to provide better moose habitat than CPRS. Moose benefits from increased browse availability associated with moderate- or heavy-intensity cuts (Vanderwel et al. 2009). Selection cutting has been suggested as an approach for maintaining caribou (Vanderwel et al. 2009), but the level of retention needs to be higher than in CPPTM. Whether or not our selection cuts maintain sufficient cover to reduce the local impact of logging on caribou remains an open question.

Our studies demonstrate that current practices (CPRS and CPPTM) have a marked effect on most of the animal groups considered here. Alternative silvicultural practices (SCt and SCp) still have an effect on some animal communities, especially on beetles, but the effect is reduced and appears even negligible for other groups.

\section{Economic Sustainability of Partial Cutting in Old-Growth Forests}

Selection cutting approaches were relatively effective in maintaining old-growth forest attributes and animal populations. The field experiment has shown that simple methods can be applied at an operational level while still providing most of the treatment potential benefits. To become widely applied, though, these experimental techniques must be economically viable. A 
profitability analysis was hence conducted, comparing SCP and CPRS, using a simulation approach with starting values derived from the field experiment (see Moore 2009, Moore et al. 2011). All costs and revenues were taken into account over a 200-year period and a Monte Carlo simulation was conducted to quantify the effects of uncertainties or variability over critical inputs. Net present value (discounted revenues minus discounted costs) was used to compare treatments.

Monte Carlo-based profitability analysis estimated that $87 \%$ and $95 \%$ of net present values would be positive for SCp and CPRS, respectively. Thus, both approaches should be profitable. However, the median value would be much higher for CPRS than for SCp, implying that it would be more profitable in most cases (Moore et al. 2011). The higher financial returns of CPRS are directly related to the first cutting operation. Subsequent cutting operations should provide positive returns only in $54 \%$ of the cases for CPRS, and up to $85 \%$ for SCp. The poor performance of future CPRS harvest operations is linked to a forecasted reduction of harvested volume and mean tree size, according to the rotation age and yield curves that were used. This situation is not expected for selection cutting. Mean harvested tree size is initially higher in selection cuts, since small trees were not targeted for removal, and future cuts will maintain this mean harvested tree size.

This analysis has shown that alternative silvicultural practices can be profitable when integrating effects over a long time frame. They also can have long-term benefits in terms of future harvests. However, the current practices remain more profitable, especially in the short term.

\section{The Future of Silvicultural Practices in Old-Growth Boreal Forests}

Our integrated experiment provides insights into the role of partial harvesting in managing late-seral (third cohort sensu Harvey et al. 2002) stands in a context of ecosystem management. Ecosystem management has become a major paradigm in forestry (Seymour et al. 2002). With this approach, we aim to preserve biodiversity by reducing the differences in stand characteristics created by forestry and those arising due to natural disturbances. For this, we need information on the type of disturbance driving natural dynamics, together with its frequency and the size of areas typically being affected. Over the last century, clearcutting has been traditionally used for managing much of the Canadian boreal forest. By systematically removing stands older than rotation age, clearcut harvesting alters the forest age structure (Cyr et al. 2009). For example, a historical reconstruction of the proportion of the Côte-Nord region of Québec affected by stand-replacing disturbances (fire and clearcutting) indicates that the abundance of young evenaged stands is already higher than the natural limits of variation (Bouchard and Pothier 2011). If this historical clearcut rate is applied in the future, the territory covered by old-growth forests will continue to decrease, which is inconsistent with the principles of ecosystem-based management.

CPRS and CPPTM impose profound changes on forest attributes and animal communities that may not be acceptable in an ecosystem management context. For this reason, other harvesting methods must also be considered to maintain socio-economic benefits while maintaining ecosystem integrity as much as possible. This experimental study is the first to look at the effects of selection cutting on such a broad range of ecosystem characteristics in irregular forests of eastern Canada. The integrated structure of the research made it possible to build direct, consistent links between treatment effects on forest attributes and various animal communities.

Even if differences between selection cutting and natural gap dynamics do exist (Angers et al. 2005, Bauhus et al. 2009), our study demonstrates that both SCt and SCp show promise in preserving important features of old-growth stands. Interestingly, even simple approaches that did not involve tree marking were able to maintain the main benefits of the treatment. These simple approaches are quite similar to the permanent cover irregular shelterwood technique described by Raymond et al. (2009), which is currently attracting interest in Québec. Even though these selection cutting methods have proven to be economically profitable and quite efficient in maintaining oldgrowth forest attributes and animal communities, many obstacles still remain to their widespread use. Probably the most important one is the short-term (i.e., at first harvest) decrease in profitability relative to clearcutting. In order for a silviculture prescription that aims at preserving old-growth stand characteristics to become attractive, society must place a financial value on "old-growthness" (Bauhus et al. 2009). Forest management certification could be seen as a market incentive in that direction.

Ecosystem forest management requires efforts at both landscape and stand levels. At the stand level, attributes of structure, species composition, and the amount of dead wood appear critical to maintain biodiversity patterns. In this context, the use of CPRS and CPPTM alone is insufficient for maintaining local biodiversity in irregularly structured, old-growth boreal forest landscapes. Thus, we recommend increasing the use of selection cutting or irregular shelterwood, especially in territories where clearcutting has reduced the area covered by old-growth forests below their historical levels. Even though it is estimated that over $60 \%$ of unmanaged stands in the Côte-Nord region have an irregular structure, it is unlikely that selection cutting will be used on such a large portion of the landbase in the short term, given the profitability issues that have already been pointed out. Nevertheless, it could become part of a management strategy applied at the landscape level, in conjunction with CPRS, CPPTM, and retention of mature stands. Green tree retention could also be integrated into CPRS to reduce some of its impacts. Selection cutting could be favoured in instances where other values need to be protected (e.g., protection of vulnerable animal species, reducing the visual impact of logging on landscapes). In the study area, caribou is a major concern that influences many forest management decisions and selection cutting could be an option to mitigate cutting impacts on this species. However, this hypothesis remains to be studied.

\section{Acknowledgements}

This research was funded by the NSERC-Laval University Industrial Research Chair in Silviculture and Wildlife. We thank our industrial partners (Abitibi-Bowater, Kruger, and Arbec) who facilitated the fieldwork and provided access to management areas. The selection cutting procedures were developed in collaboration with Jean-Martin Lussier (Canadian Wood Fibre Centre, Sainte-Foy, QC, Canada), Vincent Roy, and Philippe Meek (FPInnovations-Feric, Pointe-Claire, QC, Canada). We would also like to acknowledge the contributions of graduate students and their supervisors or co-supervisors, who were involved in individual projects (Jérôme Cimon-Morin, Marcel 
Darveau, Jean-Philippe Légaré, Christian Hébert, James Hodson, Louis Bélanger, Mélanie-Louise Leblanc, Thomas Moore, and Marc-André Lapointe).

\section{References}

Angers, V.A., C. Messier, M. Beaudet and A. Leduc. 2005. Comparing composition and structure in old-growth and harvested (selection and diameter-limit cuts) northern hardwood stands in Quebec. Forest Ecology and Management 217: 275-293.

Annand, E.M. and F.R. Thompson III. 1997. Forest bird response to regeneration practices in central hardwood forests. Journal of Wildlife Management 61: 159-171.

Azeria, E.T., D. Fortin, J. Lemaître, P. Janssen, C. Hébert, M. Darveau and S.G. Cumming. 2009. Fine-scale structure and crosstaxon congruence of bird and beetle assemblages in an old-growth boreal forest mosaic. Global Ecology and Biogeography 18: 333-345.

Bauhus, J., K. Puettmann and C. Messier. 2009. Silviculture for oldgrowth attributes. Forest Ecology and Management 258: 525-537.

Bédard, S. and F. Brassard. 2002. Les effets réels des coupes de jardinage dans les forêts publiques du Québec en 1995 et 1996. Ministère des Ressources naturelles. Gouvernement du Québec. $15 \mathrm{p}$.

Bergeron, Y., P. Drapeau, S. Gauthier and N. Lecomte. 2007. Using knowledge of natural disturbances to support sustainable forest management in the northern Clay Belt. The Forestry Chronicle 83: 326-337.

Bergeron, Y., S. Gauthier, V. Kafka, P. Lefort and D. Lessieur. 2001. Natural fire frequency for eastern Canadian boreal forest: consequences for sustainable forestry. Canadian Journal of Forest Research 31: 384-391.

Bouchard, M. and D. Pothier. 2011. Long-term influence of fire and harvesting on boreal forest age class structure and composition in eastern Québec. Forest Ecology and Management 261: 811-820.

Bouchard, M., D. Pothier and S. Gauthier. 2008. Fire return intervals and tree species succession in the North Shore region of eastern Quebec. Canadian Journal of Forest Research 38: 1621-1633.

Boucher, D., L. De Grandpré and S. Gauthier. 2003. Développement d'un outil de classification de la structure des peuplements et comparaison de deux territoires de la pessières à mousses du Québec. The Forestry Chronicle 79: 318-328.

Boutin, S. et al. 1995. Population changes of the vertebrate community during a snowshoe hare cycle in Canada's boreal forest. Oikos 74: 69-80.

Cimon-Morin, J., J.-C. Ruel and M. Darveau. 2010a. Effect of alternative silvicultural treatments on stand attributes in irregular balsam fir-black spruce stands. Forest Ecology and Management 260: 907-914.

Cimon-Morin, J., J.-C. Ruel, M. Darveau, J.-M. Lussier, P. Meek and V. Roy. 2010b. Essais de jardinage sans martelage dans des peuplements irréguliers de sapin baumier et d'épinette noire. The Forestry Chronicle 86: 498-510.

Côté, G., M. Bouchard, D. Pothier and S. Gauthier. 2010. Linking stand attributes to cartographic information for ecosystem management purposes in the boreal forest of eastern Quebec. The Forestry Chronicle 86: 511-519.

Courbin, N., D. Fortin, C. Dussault and R. Courtois. 2009. Landscape management for woodland caribou: the protection of forest blocks influences wolf-caribou co-occurrence. Landscape Ecology 24: 1375-1388.

Cyr, D., S. Gauthier, Y. Bergeron and C. Caracaillet. 2009. Forest management is driving the eastern North American boreal forest outside its natural range of variability. Frontiers in Ecology and Environment 7: 519-524.

Deans, A.M., J.R. Malcolm, S.M. Smith and M.I. Bellocq. 2005. Edge effects and the responses of aerial insect assemblages to structural retention harvesting in Canadian boreal peatland forests. Forest Ecology and Management 204: 249-266.
Deans, A.M., J.R. Malcolm, S.M. Smith and T.J. Carleton. 2003. A comparison of forest structure among old-growth, variable retention harvested, and clearcut peatland black spruce (Picea mariana) forests in boreal northeastern Ontario. The Forestry Chronicle 79: 579-589.

De Grandpré, L., J. Morisette and S. Gauthier. 2000. Long-term post fire changes in the northeastern boreal forest of Quebec. Journal of Vegetation Science 11: 791-800.

Desponts, M., G. Brunet, L. Bélanger and M. Bouchard. 2004. The eastern boreal old-growth balsam fir forest: a distinct ecosystem. Canadian Journal of Botany 82: 830-849.

Dlott, F. and R. Turkington. 2000. Regulation of boreal forest understory vegetation: the roles of resources and herbivores. Plant Ecology 151: 239-251.

Doucet, R. and J. Boily. 1995. Croissance en hauteur de la régénération d'épinette noire et de sapin baumier après la coupe. Québec, direction de la recherche forestière, Note de recherche forestière no 68. 4 p.

Ferron, J., F. Potvin and C. Dussault. 1998. Short-term effects of logging on snowshoe hares in the boreal forest. Canadian Journal of Forest Research 28: 1335-1343.

Fortin, D. et al. 2011. Partial cutting in old-growth boreal forests and the preservation of animal diversity from ants to woodland caribou. In E.B. Wallace (ed.). Woodlands: ecology, management and conservation. pp. 115-136. Nova Science Publishers, Inc., New York.

Foster, D.R. 1983. The history and pattern of fire in the boreal forest of southeastern Labrador. Canadian Journal of Botany 61: 2459-2470.

Fuller, A.K., D.J. Harrison and H.J. Lachowski. 2004. Stand scale effects of partial harvesting and clearcutting on small mammals and forest structure. Forest Ecology and Management 191: 373-386.

Grondin, P., J. Noël and D. Hotte. 2003. Envahissement des parterres de coupe par le sapin en forêt boréale. In P. Grondin and A. Cimon (coords.). Les enjeux de biodiversité relatifs à la composition forestière. pp. 15-44. Ministère des Ressources naturelles, de la Faune et des Parcs, Direction de la recherche forestière et Direction de lenvironnement forestier, Québec, QC.

Groot, A. 2002. Is uneven-aged silviculture applicable to peatland black spruce (Picea mariana) in Ontario, Canada? Forestry 75: 437-442.

Groot, A., J.M. Lussier, A.K. Mitchell and D.A. MacIsaac. 2005. A silvicultural systems perspective on changing Canadian forestry practices. The Forestry Chronicle 81: 50-55.

Hansen, A.J., T.A. Spies, F.J. Swanson and J.L. Ohmann. 1991. Conserving biodiversity in managed forests: lessons from natural forests. BioScience 41: 382-39.

Harmon, M.E. et al. 1986. Ecology of coarse woody debris in temperate ecosystems. Advances in Ecology Research 15: 133-302.

Harrison, R.B., F.K.A. Schmiegelow and R. Naidoo. 2005. Standlevel response of breeding forest songbirds to multiple levels of partial-cut harvest in four boreal forest types. Canadian Journal of Forest Research 35: 1553-1567.

Harvey, B., A. Leduc, S. Gauthier and Y. Bergeron. 2002. Standlandscape integration in natural disturbance-based management of the southern boreal forest. Forest Ecology and Management 155: 369-385. Hodson, J. 2011. Sélection d'habitat du lièvre d'Amérique en forêt boréale irrégulière aménagée. Ph.D. Thesis, Université Laval, Québec, QC. $196 \mathrm{p}$.

Hodson, J., D. Fortin, M.-L. LeBlanc and L. Bélanger. 2010. An appraisal of the fitness consequences of forest disturbance for wildlife using habitat selection theory. Oecologia 164: 73-86.

Janssen, P., C. Hébert and D. Fortin. 2011. Biodiversity conservation in old-growth boreal forest: black spruce and balsam fir snags harbour distinct assemblages of saproxylic beetles. Biodiversity and Conservation 20: 2917-2932.

Jonsson, B.G. and N. Kruys. 2001. Ecology of woody debris in boreal forests. Wiley-Blackwell, Hoboken, NJ.

LeBlanc, M.L. 2009. Réactions des micromammifères et des oiseaux à différentes intensités de coupe en forêt boréale irrégulière. M.Sc. thesis, Université Laval, Québec, QC. 40 p. 
Leblanc, M.-L., D. Fortin, M. Darveau and J.-C. Ruel. 2010. Short-term response of small mammals and forest birds to silvicultural practices differing in tree retention in irregular boreal forests. Ecoscience 17: 334-342.

Légaré, J.-P., C. Hébert and J.-C. Ruel. 2011. Alternative silvicultural practices in boreal irregular forests: response of beetle assemblages. Silva Fennica 45: 937-956.

Lemaître, J., D. Fortin, D.W. Morris and M. Darveau. 2010. Deer mice mediate red-backed vole behaviour and abundance along a gradient of habitat alteration. Evolutionary Ecology Research 12: 203-216.

McCarthy, J.W. and G. Weetman. 2006. Age and size structure of gap-dynamic, old-growth boreal forest stands in Newfoundland. Silva Fennica 40: 209-230.

McComb, W.C., T.A. Spies and W.H. Emmingham. 1993. Douglasfir forests: Managing for timber and mature-forest habitat. Journal of Forestry 91: 31-42.

Meek, P. and J.-M. Lussier. 2008. Essais de coupes partielles de forêts hétérogènes par l'approche multitraitement. FPInnovations-Feric. Avantage 10(2): 15.

MRNFPQ. 2003. Manuel d'aménagement forestier du Québec (4th edition). Ministère des Ressources naturelles de la Faune et des Parcs, Charlesbourg, QC.

Moore, T.Y. 2009. Analyse financière avec simulations Monte Carlo de nouveaux traitements de coupes de jardinage en forêt résineuse irrégulière au Québec. M.Sc. thesis, Université Laval, Québec, QC. 153 p. Moore, T.Y., J.-C. Ruel, M.-A. Lapointe and J.-M. Lussier. 2011. Evaluating the profitability of selection cuts in irregular boreal forests: An approach based on Monte Carlo simulations. Forestry doi:10.1093/ forestry/cpr057.

Pohl, G.R., D.W. Langor and J.R. Spence. 2007. Rove beetles and ground beetles (Coleoptera: Staphylinidae, Carabidae) as indicators of harvest and regeneration practices in western Canadian foothills forests. Biological Conservation 137: 294-307.

Pothier, D., R. Doucet and J. Boily. 1995. The effect of advance regeneration height on future yield of black spruce stands. Canadian Journal of Forest Research 25: 536-544.

Raymond, P., S. Bédard, V. Roy, C. Larouche and S. Tremblay. 2009. The irregular shelterwood system: review, classification, and potential application to forests affected by partial disturbances. Journal of Forestry 107: 405-413.

Riopel, M., J. Bégin and J.F. Gingras. 2000. Une option pour la récolte en forêt boréale: la coupe avec protection des petites tiges marchandes. Avantage 1(17): 8.
Robitaille, A. and J.-P. Saucier. 1998. Paysages régionaux du Québec méridional. Publications du Québec, Sainte-Foy, Québec. 213 p.

Ruel, J.-C. 1989. Importance de la régénération préexistante dans les forêts publiques du Québec. Annales des Sciences Forestières 46: 345-359.

Ruel, J.-C. 1995. Understanding windthrow: Silvicultural implications. The Forestry Chronicle 71: 434-445.

Ruel, J.-C. 2000. Factors influencing windthrow in balsam fir forests: from landscape studies to individual tree studies. Forest Ecology and Management 135: 169-178.

Ruel, J.-C., V. Roy, J.-M. Lussier, D. Pothier, P. Meek and D. Fortin. 2007. Mise au point d’une sylviculture adaptée à la forêt boréale irrégulière. The Forestry Chronicle 83: 367-374.

Savill, P.S. 1983. Silviculture in windy climates. Forestry Abstracts 44: 473-488.

Seymour, R.S., A.S. White and P.G. deMaynadier. 2002. Natural disturbances in northeastern North America-evaluating silvicultural systems using natural scales and frequencies. For. Ecol. Manage. 155: 357-367.

Simon, N.P.P., F.E. Schwab and A.W. Diamond. 2000. Patterns of breeding bird abundance in relation to logging in western Labrador. Canadian Journal of Forest Research 30: 257-263.

Smith, D.M., B.C. Larson, M.J. Kelty and P.M.S. Ashton. 1997. The practice of silviculture: Applied forest ecology. John Wiley \& Sons, New York.

Speight, M.C.D. 1989. Saproxylic invertebrates and their conservation. Nature and Environment Series 42. Strasbourg. 79 p.

Steventon, J.D., K.L. MacKenzie and T.E. Mahon. 1998. Response of small mammals and birds to partial cutting and clearcutting in northwest British Columbia The Forestry Chronicle 74: 103-113.

Vanderwel, M.C., J.R. Malcolm and S.C. Mills. 2007. A meta-analysis of bird responses to uniform partial harvesting across North America. Conservation Biology 21: 1230-1240.

Vanderwel, M.C., S.C. Mills and J.R. Malcolm. 2009. Effects of partial harvesting on vertebrate species associated with late-successional forests in Ontario's boreal region. The Forestry Chronicle 85: 91-104.

Viereck, L.A and W.F. Johnston. 1990. Black spruce. In R.M. Burns and B.H. Honkala (technical coordinators). Silvics of North America, Vol. 1, Conifers. USDA Forest Service Agriculture Handbook 654, Washington, DC.

Youngblood, A. and B. Titus. 1996. Clearcutting - a regeneration method in the boreal forest. The Forestry Chronicle 72: 31-36. 